\title{
SARS-CoV-2 serostatus of healthcare worker in the Austrian state Vorarlberg between June 2020 and January 2021
}

\author{
Michele ATZL MD ${ }^{1}$, Axel MUENDLEIN PhD ${ }^{2}$, Thomas WINDER MD ${ }^{1}$, Peter FRAUNBERGER MD \\ ${ }^{3,4}$, Eva-Maria BRANDTNER PhD ${ }^{2}$, Kathrin GEIGER PhD ${ }^{2,3}$, Miriam KLAUSBERGER PhD ${ }^{5}$, Mark \\ DUERKOP PhD ${ }^{5}$, Lukas SPRENGER MD ${ }^{1,2}$, Beatrix MUTSCHLECHNER MD ${ }^{1,4}$, Andreas \\ VOLGGER MD ${ }^{1}$, Magdalena BENDA MD ${ }^{1}$, Luciano SEVERGNINI MD ${ }^{1}$, Johannes B. JAEGER \\ MD ${ }^{1}$, Heinz DREXEL MD ${ }^{2,4,6,7}$, Alois LANG MD ${ }^{8}$, and Andreas LEIHERER PhD ${ }^{2,3,4}$
}

\section{Affiliations}

${ }^{1}$ Department of Internal Medicine II, Academic Teaching Hospital Feldkirch, Feldkirch, Austria

${ }^{2}$ Vorarlberg Institute for Vascular Investigation and Treatment (VIVIT), Feldkirch, Austria

${ }^{3}$ Medical Central Laboratories, Feldkirch, Austria

${ }^{4}$ Private University of the Principality of Liechtenstein, Triesen, Liechtenstein

${ }^{5}$ Department of Biotechnology, University of Natural Resources and Life Sciences (BOKU) Vienna,

Vienna, Austria

${ }^{6}$ Department of Internal Medicine, Academic Teaching Hospital Bregenz, Bregenz, Austria

${ }^{7}$ Drexel University College of Medicine, Philadelphia, PA, USA

${ }^{8}$ Cancer Registry Vorarlberg, Agency for Preventive and Social Medicine, Bregenz Austria

\section{Address for correspondence}

Andreas Leiherer

Vorarlberg Institute for Vascular Investigation and Treatment (VIVIT),

Academic Teaching Hospital Feldkirch, Feldkirch, Austria

Carinagasse 47, A-6800 Feldkirch, Austria; E-mail address: vivit@lkhf.at 


\section{Main summary}

A relatively low percentage of $3 \%$ SARS-CoV-2 seropositive HCW with strong IgG-specific antibody responses was found in the Austrian federal state Vorarlberg after the first wave increasing to $14 \%$ after the second massive wave lasting until January 2021.

\section{Funding and disclosures}

This work received a particular funding from FFG (project number 880956). No potential conflicts of interest relevant to this article were reported by M.A., A.M., T.W., P.F., E.M.B., K.G., M.K., M.D., L.Sp., B.M., A.V., M.B., L.Se., J.J., H.D., A.La., and A.Le..

\section{Data sharing statement}

The data that support the findings of this study are available from the corresponding author upon reasonable request. 


\section{Abstract}

\section{Background}

Austria, and particularly its westernmost federal state Vorarlberg, developed an extremely high COVID-19 incidence rate in November 2020. Health care workers (HCW) may be at higher risk of contracting the disease within the working environment and therefore the seroprevalence in this population is of particular interest. Here, we analyzed SARS-CoV-2specific antibody response in Vorarlberg HCW in a prospective cohort study.

\section{Methods}

A total of $395 \mathrm{HCW}$ have been tested at three different time points for the prevalence of antiSARS-CoV-2 IgG antibodies specific for NP and RBD. Enrollment started in June $2020\left(t_{1}\right)$, two months after the end of the first wave. Re-testing took place between October to November at the beginning of the second wave $\left(t_{2}\right)$, and again at the end of the second wave in January $2021\left(\mathrm{t}_{3}\right)$.

\section{Results}

At $t_{1}, 3 \%$ of HCW showed a strong IgG-specific responses to either NP or RBD. At $t_{2}$, the rate increased to $4 \%$, and after the second wave in January $2021,14 \%$ had a strong response, which was assessed to be stable for up to ten months. The amount of HCW with anti-SARSCoV-2 IgG antibodies was 38\% higher than the number of infections found by RT-PCR.

\section{Conclusion}

We found low numbers of SARS-CoV-2-seropositive HCW in a hotspot setting after the first wave but a very high increase during the second massive wave. Though the seroprevalence in HCW was comparable to the general population. Our findings offer support for the routine application of serological testing in management of the ongoing COVID-19 pandemic.

\section{[Keywords]}

Health care workers; HCW; COVID-19; SARS-CoV-2; IgG; spike protein; RBD; NP seroconversion; seroprevalence 


\section{Introduction}

In March 2020 the coronavirus disease 2019 (COVID-19) was declared a global pandemic by the World Health Organization (WHO), with Europe at the time as the epicenter. The high numbers of cases and associated mortality first overwhelmed health care services in Northern parts of Italy (1). Several independent introducing events, mainly from Northern Italy have most likely contributed to clusters in Austria (2) and further enforced the spread in many other European countries (3) during the so called first wave in March 2020. During the second and by far higher wave, peaking in Austria in November, Austria developed the highest incidence rate worldwide (4) and the federal state of Vorarlberg, despite a low degree of urbanization, reported one of the highest rates in Austria (5).

Health care workers (HCW) are on the first line of defense and have a high risk of becoming infected and infecting others with SARS-CoV-2 (6). This has been first demonstrated in China (7) and has been confirmed in early reports from Italy, where HCW have represented $9 \%$ of total cases (1).

In contrast to real time reverse transcription polymerase chain reaction (RT-PCR) assays detecting SARS-CoV-2 for only 2-3 weeks after infection (8), the immunoglobulin (Ig) Gspecific response to SARS-CoV-2 epitopes is typically detectable in serum about two weeks after symptom onset (9). At least $95 \%$ of PCR-confirmed SARS-CoV-2 infected patients develop specific anti-SARS-CoV-2 antibodies (10). The receptor binding domain (RBD) of the spike protein has meanwhile become the most common antigen of seroconversion assays, as it has received FDA emergency approval (11) and has also been shown to correlate well with neutralizing activity $(10,12-14)$.

This study thus investigates the dynamics of IgG-specific response against RBD and the nucleocapsid protein (NP) of SARS-CoV-2 in serial serum samples collected from $395 \mathrm{HCW}$ after the first wave (June - August 2020), at the beginning of the second massive wave (October 2020), and the end of the second wave (January 2021) using enzyme linked immunosorbent assay (ELISA) . 


\section{Methods}

\section{Study subjects}

This study comprises 395 participants of mainly Caucasian origin with a median age of 42 (min. 18 - max. 64) years working as HCW in Vorarlberg, the westernmost federal state of Austria. All participants are employed by either of the Vorarlberg state hospitals and 174 (44\%) at a COVID-19-specialized hospital.

Study enrolment was voluntary and at no charge for the participants. All subjects reported to be in healthy condition. Inclusion rested solely towards the purpose of antibody determination and was not influenced or motivated by the presence of signs or symptoms of disease. At the time point of recruiting, participants completed a survey form which prompted for demographic information as well symptoms of COVID-19 infection in the three months prior to collection of serum sample. Additionally, data on SARS-CoV-2-specific RT-PCR test were collected, which had been ordered by the hospital at any suspicion of a possible infection. All participants gave written informed consent and the present study conforms to the ethical guidelines of the 1975 Declaration of Helsinki and has been approved by the Ethics Committee of Vorarlberg (EK-2-4/2020).

After the first wave in March 2020 and after the first harsh lockdown in Austria $\left(16^{\text {th }}\right.$ of March to $30^{\text {th }}$ of April) blood samples were collected. Collection took place between $26^{\text {th }}$ of June and $19^{\text {th }}$ of August 2020 and is referred to as time point $1\left(t_{1}\right)$. Identical criteria were applied for the second round of sampling between $2^{\text {nd }}$ October and $13^{\text {th }}$ November $\left(t_{2}\right)$ and the third round between $7^{\text {th }}$ and $20^{\text {th }}$ January $2021\left(t_{3}\right)$. Thus, sampling at $t_{2}$ took place mostly at the beginning of the second wave 2020 and at $t_{3}$ after the second wave, during the third harsh lockdown in Austria ( $17^{\text {th }}$ November to $6^{\text {th }}$ December). A summary of the study timeline is given in figure 1. Data on 7-day incidence were obtained from open government data by the Austrian Federal Ministry of Social Affairs, Health, Care and Consumer Protection (15). Only 5 out of 395 participants were missing at $t_{2}$ and 24 at $t_{3}$ due to end of employment, withdrawal of consent, or due to other reasons. Hence, the follow-up rate at $t_{2}$ was $99 \%$ and $94 \%$ at $t_{3}$. 


\section{Study data and laboratory analyses}

Study data were collected and managed using REDCap electronic data capture tools (16, 17) hosted at VIVIT. Acute SARS-CoV-2 infection was determined by virus detection through RT-PCR of nasopharyngeal swabs at the Institute of Pathology, Academic Teaching Hospital Feldkirch (Feldkirch, Austria). At each time point, venous blood was collected, processed, and anti-SARS-CoV-2 antibodies were detected in human serum via an ELISA specifically detecting IgGs directed against the recombinant NP RBD (5600100 Technozym, Technoclone, Vienna, Austria, (13)) according to the manufacturer's protocol. Concentrations were calculated according to internal calibration standards using the Xlfit software package (Version 5.3.1.3, IDBS) with $1 \mathrm{U} / \mathrm{mL}$ representing $100 \mathrm{ng} / \mathrm{ml}$ of a SARS-specific antibody (18).

According to manufacturer's protocol, values $<5 \mathrm{U} / \mathrm{mL}$ were referred to as normal or background range representing no SARS-CoV-2-specific antibody response. Values $\geq 5$ $\mathrm{U} / \mathrm{mL}$ were referred to as positive responses. The $5 \mathrm{U} / \mathrm{mL}$ cutoff was defined on basis of criteria suggested by the Youden index and the $99^{\text {th }}$ percentile method (19). Values $\geq 5$ and $<9 \mathrm{U} / \mathrm{mL}$ for anti-SARS-CoV-2 RBD-specific antibody response or $\geq 5$ and $<8 \mathrm{U} / \mathrm{mL}$ for antiSARS-CoV-2 NP-specific antibody responses were referred to as a moderate positive response. In terms of the prevalence nature of the study, a higher cut-off of $\geq 9 \mathrm{U} / \mathrm{mL}$ was chosen for anti-SARS-CoV-2 RBD $\lg$ and $\geq 8 \mathrm{U} / \mathrm{mL}$ for anti-SARS-CoV-2 NP IgG to increase specificity, as proposed by the manufacturer and by a previous study (19). Values $\geq 9$ and $\geq 8 \mathrm{U} / \mathrm{mL}$, respectively were thus referred to as a strong positive response. IgG concentration was measured at time points $t_{1}, t_{2}$, and $t_{3}$. Participants whose antibody levels increased between time points from background to moderate, from moderate to strong, or from background to strong response were referred to as converters. Participants with (i) a moderate or strong response at an earlier time point and (ii) no conversion during following time points and (iii) a declined or unchanged response (including also marginally increased responses not higher than $10 \%$ or $1 \mathrm{U} / \mathrm{mL}$, respectively) were referred to as moderate or 
strong response decliner, respectively. The half-life of antibody response as well as the time until antibody response has dropped under the $5 \mathrm{U} / \mathrm{mL}$ threshold for seropositivity was extrapolated, assuming an exponential decline.

\section{Statistical analysis}

Differences in baseline characteristics were tested for statistical significance with Chisquared tests for categorical variables, with Mann-Whitney-U tests for continuous, not normally distributed, and unpaired continuous variables, and with Wilcoxon tests for continuous, not normally distributed, and paired variables, respectively. Correlation analyses were performed calculating nonparametric Spearman rank correlation coefficients. Results are given as mean if not denoted otherwise, and $p$-values of 0.05 were considered significant. All statistical analyses were performed with SPSS 26.0 for Windows (IBM corp., USA), and R statistical software v. 3.5.1 (http://www.r-project.org). 


\section{Results}

\section{Seroprevalence between June 2020 and January 2021}

The study timeline is summarized in figure $\mathbf{1}$ and the characteristics of our study participants in table 1 (further data on residence and profession are summarized in supplemental table 1). The anti-SARS-CoV-2 specific IgGs against RBD and NP were assessed at three time points, after first wave $\left(t_{1}\right)$, at the beginning of second wave $\left(t_{2}\right)$, and after second wave $\left(t_{3}\right)$. The respective mean concentrations, the correlation of RBD- to NP- specific IgGs, as well as the proportion of seropositive subjects (5 U/mL cut-off) and in particular the seropositive subjects with a strong response (strong responder: $9 \mathrm{U} / \mathrm{mL}$ cut-off) are summarized in table 2 and figure 2 for the three time points $t_{1}, t_{2}$, and $t_{3}$. Overall, $73(18 \%)$ out of all $395 \mathrm{HCW}$ have been tested at least once positive at any time point $\left(t_{1}, t_{2}\right.$, or $\left.t_{3}\right)$ during the study.

\section{Change of antibody response during study}

The range of RBD- and NP-specific antibody response between time point $t_{1}$ and $t_{3}$ is depicted in figure $\mathbf{3}$ and the change is summarized in supplemental table 2. Overall, the RBD- and NP-specific IgG concentration increased during the study. Between $t_{1}$ and $t_{3}, 44$ (12\%) seroconverted to a strong response $\left(t_{1}-t_{3}\right.$-strong response converter) and $6(2 \%)$ to a moderate response $\left(t_{1}-t_{3}\right.$-moderate response converter). Out of these $44 t_{1}-t_{3}$-strong response converter, 43 converted from no response at $t_{1}$ to a strong response at $t_{3}$, and only one participant from a moderate response to a strong response. The mean increase of these $44 \mathrm{t}_{1}-\mathrm{t}_{3}$-strong response converter was 42.3 -fold for RBD- and a 43.7 -fold for NP-specific antibody response; for the $6 \mathrm{t}_{1}-\mathrm{t}_{3}$-moderate converters 3.5-fold and 2.3-fold, respectively.

Further, $19 \mathrm{HCW}$ were found to have a declined antibody response between $t_{1}$ and $t_{3}\left(t_{1}-t_{3}-\right.$ decliner). Of these, nine had a strong response at $t_{1}\left(t_{1}-t_{3}-\right.$ strong response decliner) and ten a moderate response $\left(t_{1}-t_{3}\right.$-moderate response decliner). The decrease of antibody response between $t_{1}$ and $t_{3}$ (5.7 months) and between $t_{2}$ and $t_{3}$ (2.8 months) is summarized in 
supplemental table 2. Taking into account the $t_{1}-t_{3}$ and $t_{2}-t_{3}$ time overlap, in total, 23 individuals have declined antibody responses between measurements at $t_{1} / t_{2}$ and $t_{3}$ during a median time of 5.0 months. Overall, the RBD-and NP-specific antibody response of these 23 decliner has decreased by $19 \%$ per month for both. The monthly decline of antibody response was significantly correlated with the strength of response measured at $t_{1} / t_{2}$ with an $r$ of $0.706(p<0.001)$ for RBD and an $r$ of $0.887(p<0.001)$ for NP (supplemental figure 1). Strong responders had a more pronounced monthly decline than moderate responder and the proportional decline between $t_{2}$ and $t_{3}$ was comparable to the one between $t_{1}$ and $t_{3}$ in spite of the shorter time span (supplemental table 2). Taking into account that exponential decline, the median half-life of RBD- and NP-specific responses were 5.5 [2.3-15.8] and 5.7 [2.2-11.2] months. In addition, the median time in which a positive antibody response (5 $\mathrm{U} / \mathrm{mL}$ cut-off) for either RBD or NP can be maintained was 6.0 [1.6-19.8] months for all decliners and 10.2 [6.3-23.4] months for the strong-response decliner.

Of note, we did not find any elimination of a strong response between $t_{1}$ and $t_{2}$ or between $t_{1}$ and $t_{3}$. In contrast, out of the mentioned 12 moderate responders at $t_{1}$ only 3 had still a moderate response at $t_{3}, 1$ resigned, 1 converted to a strong response, and 7 did not reach the cut-off for moderate response at $t_{3}$.

\section{Association of antibody response with RT-PCR data.}

Out of $395 \mathrm{HCW}$ tested for SARS-CoV-2-specific IgGs, 249 have also been tested at least once for the presence of an acute infection with SARS-CoV-2 during the study by RT-PCR and 53 of these were positive. As mentioned above, applying ELISA, 73 out of all $395 \mathrm{HCW}$ have been tested at least once positive for SARS-CoV-2-specific IgGs during the study. Thus, the number of HCW with ELISA-assessed positive antibody response is $38 \%$ higher $(n=20)$ than infections detected by RT-PCR in the whole study population.

Taking into account only HCW who have been tested by both methods, RT-PCR and ELISA, we found that only four RT-PCR-positive HCW had no antibody response, reflecting an antibody response rate of $92 \%$ in RT-PCR-positive tested HCW. In contrast, only $73 \%$ of 
medRxiv preprint doi: https://doi.org/10.1101/2021.02.19.21252045; this version posted February 26, 2021. The copyright holder for this preprint

(which was not certified by peer review) is the author/funder, who has granted medRxiv a license to display the preprint in perpetuity.

It is made available under a CC-BY-NC-ND 4.0 International license .

HCW with an antibody response have also been tested RT-PCR-positive (46/63). Regarding a strong antibody response, only $83 \%$ have been tested RT-PCR-positive (43/52).

\section{Association of antibody response with COVID-19-symptoms and further parameters}

Taking into account the survey data, HCW who had COVID-19-symptoms at $t_{3}$ were significantly more likely to be seropositive than asymptomatic ones $(36 \%$ vs. $8 \% p<0.001)$, but this was not the case at $t_{1}(p=0.193)$ or $t_{2}(p=0.645)$. Further, there was no significant difference between male and female HCW being seropositive at any time point $(21 \%$ vs. $18 \%, \mathrm{p}=0.518)$ or between $\mathrm{HCW}$ with a $\mathrm{BMI} \geq 25$ compared to those with $\mathrm{BMI}<25(22 \%$ vs. $17 \%, p=0.226)$. HCW above 40 years had a similar prevalence compared to younger ( $\leq 40$ years) ones ( $16 \%$ vs. $18 \%, p=0.603)$ and participants sharing their household with children or adolescents younger than 25 years had no significantly increased risk for being seropositive compared to participants without younger persons in their households (19\% vs. $14 \%, p=0.202)$. HCW working at a regular hospital had a slightly but not significantly lower prevalence than those at a COVID-19-specialized hospital (14\% vs. $21 \%, p=0.068)$ and also smokers had a lower prevalence, which just failed significance ( $9 \%$ vs. $18 \%, p=0.060)$. 


\section{Discussion}

\section{Main findings}

In our study the antibody response was clearly higher after the second massive wave compared to the first wave reflecting the incidence rate in Austria (figure 1 and (15)). Of note, the number of undetected SARS-CoV-2 infections during our study was quite high as only $83 \%$ of HCW with a strong antibody response, have previously been identified by RTPCR.

Moreover, a conversion to a strong response during the study was much more likely than conversion to a moderate response only and a strong response was more stable than a moderate response.

A further important finding was that we found no elimination of a strong response during the study: All participants with a strong response maintained a positive response during the study and, according to extrapolation, will keep it for 10 months. Similarly, the half-life of positive antibody responses was about six months for both, the RBD- and NP-specific response.

\section{Seroprevalence after the first wave in the light of other study data on HCW}

Our data revealing a $3 \%$ seroprevalence at $t_{1}$, after the first wave, are slightly above those from HCW in Germany $(20,21)$ and Italy, apart from the North $(22,23)$ being in the range of $1-2 \%$ around the same time. Higher rates of $5-6 \%$ were seen in the Veneto Region, Italy (24), Belgium (25), Norway (26) and Northern England, UK (27). One of the highest incidence rates of COVID-19 infections in the world were seen in the U.S., with and a seroprevalence rate of $19 \%$ in the general population (28) and $27 \%$ in HCW at the New York City Hospital South Bronx at the same time (29). Almost similar rates were found in HCW in Sweden (19\%) (30) and some parts of the U.K. namely London (32\%) (31) and Birmingham (24\%) (32). Nevertheless, these rates are still below the seropositivity rate of $67 \%$, which has 
initially been estimated as threshold for community immunity against SARS-CoV-2 (33) and now has been estimated to be as high as $85 \%$ according to CDC (34).

\section{Seroprevalence at the beginning and at the end of the second wave}

A recent seroprevalence study of the general population in Austria comprising 2229 participants and collecting samples between $12^{\text {th }}$ to $14^{\text {th }}$ November, which took place during the second wave found neutralizing antibodies in 92 samples reflecting a seroprevalence of $4.7 \%(35)$. This is just matching our data about the same time $\left(\mathrm{t}_{2}\right)$ and thus proposes that HCW in Vorarlberg were well prepared facing the challenges by COVID-19 in the local health care system although they might have a higher chance of being infected than the general population. Passing the second wave, Austria had one of the highest incidence rates in the world (4) and the seroprevalence after the second wave has been hypothesized to be about $15 \%$ in the general population (36). Around the same time, at $t_{3}$ of our study, we found a massive increase to $14 \%$, having a strong antibody response. This proposes again that $\mathrm{HCW}$ in Vorarlberg may have had an infection rate comparable to the general population. As all HCW in Vorarlberg had the opportunity for vaccination starting at $7^{\text {th }}$ January, it remains speculative whether the seroprevalence might have further increased or plateaued.

\section{Seroconversion, protection and reinfection}

Even though our study primarily aimed at observing the prevalence of seroconversion of all HCW during first and second wave of the COVID-19 pandemic, focusing only on the subgroup of responder we found that, a strong response was more stable than a moderate response.

These findings are in good alignment with the very fast increase in antibody titers and neutralization within only 10 days after symptom onset, tested with the same assay (19). All participants who once have developed a strong response maintained a positive response, either still a strong one or at least a moderate one, during the full study time. An extrapolation thus suggests that these strong responders will keep their response for about ten months. 
This is in line with previous data of recent studies in the UK and Spain, demonstrating that SARS-CoV-2 infection-acquired immunity is present for at least six months $(14,25)$ and suggesting that protective immunity will last up to a few years (14). A further study in New York City has found only a moderate decline regarding the spike protein-specific response during five months (10). We here report a mean decline of $51 \%$ and $60 \%$ during five months for RBD- and NP-specific responses, respectively. A decrease of $17 \%$ and $31 \%$ for antispike $\lg G$ and anti-NP $\lg$ titers has been reported in a study comprising 847 workers at Institute Curie in Paris, France during 4-8 weeks thus accounting a rather short-lived immune responses with only 87 days for anti-spike $\lg G$ and 35 days for anti-NP $\lg G$ s, respectively (12). Wajnberg et al. have suggested that the stability of the antibody response over time may depend on the serologic target (10) with a faster decline of NP compared to RBD. Other than NP, the spike protein is the main and potentially the only target for neutralizing antibodies (37). It thus appears that the RBD is more suited than NP for surveillance of longterm immune response by ELISA. Nevertheless, RBD-specific IgG response as investigated in our study as well as in most others on seroprevalence is only a fragment of the very complex post-infection immunity and longevity of response.

Finally, we also have noticed one case in which a moderate antibody response at $t_{1}$ has converted to a strong response at $t_{3}$, most likely representing a reinfection. That said, the number of responders at $t_{1}$ and $t_{2}$ is small compared to the initial study number and thus the conclusions (including those regarding reinfection, immunity, elimination time, and half-life) for this subgroup are limited and should be taken with care. Further limitations are mentioned in the following.

\section{Limitations}

This study is not a random sample of either the general population or the HCW of Vorarlberg. Included are voluntary and of age HCW. Results are not necessarily applicable to the general population and especially not to children or elderly people ( $\geq 65$ years). At least some results should be interpreted with caution, as it is possible that some of our participants 
which have been classified to "no response" due to a response below the assay cut-off of $<5$ $\mathrm{U} / \mathrm{mL}$ were infected with SARS-CoV-2 a few months before sampling, and either have had only a low antibody response post-infection, and/or have already dropped below the assay threshold. Apart from that, our study only gives information about post-infection antibodyresponse and not about immunity or the chance of reinfections. In that context, it is impossible to fully explain the nature of change of antibody-specific responses in our study, e.g. for responders of which some may be impacted by a secondary contact to the virus thus acting as kind of a booster. Furthermore, it has already been demonstrated that a NP- or spike-specific antibody response may not always be present following a proven SARS-CoV-2 infection (12). Apart from that, a large variety of different commercial ELISAs has been used for the above-mentioned serological study data. Although IgG-specific ELISAs have been proposed to be appropriate for prevalence testing, accuracy significantly differs between different serological testing methods (38), thus, the between-comparison should always be done with caution. Finally some participants have been vaccinated during sampling at $t_{3}$, but in no case vaccination took place more than one week before sampling. Antibody responses are generally not mounted within one week after vaccination (39), and converters at $t_{3}$ who have been vaccinated had responses for RBD and NP thus we preclude an effect of the RBD-based vaccine.

\section{Implications for health policy and clinical perspectives}

Given the limitations mentioned above, the antibody response is yet widely used as a surrogate for deciding whether post-infection immunity to SARS-CoV-2 exists and the antibody response in our study has proven to persist for several months. That said, our and others' findings do not support exempting those positive for anti-SARS-CoV-2 antibodies from current infection control, other public health constraints, or the ongoing vaccination. Anyway, the current seroprevalence of HCW is far beyond any herd immunity threshold

Our findings suggest serological testing as routine application for determining and monitoring the success of detecting acute infections and is therefore an important tool managing the 
ongoing COVID-19 pandemic. Given the 38\% higher number of HCW with antibody response than RT-PCR-verified infections assessed by routine surveillance, and the at least $17 \%$ undetected infections of HCW in our hospitals recommends a massively increased infection surveillance, either by routine serological, PCR-based, other test strategies e.g. daily lateral flow tests. Apart from that, further studies are necessary to determine the long-time duration of post-infection antibody response and immunity and compare it to vaccination data as this has major implications for the future of the current SARS-CoV-2 pandemic and public health system. For the particular study participants, the ELISA may also be very helpful for determining the success of vaccination. We plan to continue this longitudinal serosurvey for several months analyzing the antibody response after vaccination started in Austria at January 2021.

\section{Acknowledgments}

We are grateful to the Vorarlberger Landesregierung (Bregenz, Austria) for continuously supporting our research institute. We are also grateful to all state hospitals in Vorarlberg and in particular to the Institute of Pathology at the Academic Teaching Hospital Feldkirch for their support. The present study was funded by the Austrian Research Promotion Agency (FFG). 


\section{References}

1. Livingston E, Bucher K. 2020. Coronavirus Disease 2019 (COVID-19) in Italy. JAMA 323:1335.

2. Knabl L, Mitra T, Kimpel J, Rössler A, Volland A, Walser A, Ulmer H, Pipperger L, Binder SC, Riepler L, Bates K, Bandyopadhyay A, Schips M, Ranjan M, Falkensammer B, Borena W, Meyer-Hermann M, von Laer D. 2020. High SARS-CoV-2 Seroprevalence in Children and Adults in the Austrian Ski Resort Ischgl. medRxiv doi.org/10.1101/2020.08.20.20178533.

3. Kreidl P, Schmid D, Maritschnik S, Richter L, Borena W, Genger JW, Popa A, Penz T, Bock C, Bergthaler A, Allerberger F. 2020. Emergence of coronavirus disease 2019 (COVID-19) in Austria. Wien Klin Wochenschr 132.

4. Our World in Data. 2020. Austria: Coronavirus Pandemic Country Profile; https://ourworldindata.org/coronavirus/country/austria?country= AUT.

5. AGES - Austrian Agency for Health and Food Safety Ltd. 2021. AGES Dashboard COVID19; https://covid19dashboard.ages.at/dashboard.html.

6. Nguyen LH, Drew DA, Graham MS, Joshi AD, Guo CG, Ma W, Mehta RS, Warner ET, Sikavi DR, Lo CH, Kwon S, Song M, Mucci LA, Stampfer MJ, Willett WC, Eliassen AH, Hart JE, Chavarro JE, Rich-Edwards JW, Davies R, Capdevila J, Lee KA, Lochlainn MN, Varsavsky T, Sudre CH, Cardoso MJ, Wolf J, Spector TD, Ourselin S, Steves CJ, Chan AT, Albert CM, Andreotti G, Bala B, Balasubramanian BA, Beane-Freeman LE, Brownstein JS, Bruinsma FJ, Coresh J, Costa R, Cowan AN, Deka A, Deming-Halverson SL, Elena Martinez M, Ernst ME, Figueiredo JC, Fortuna P, Franks PW, Freeman LB, Gardner CD, Ghobrial IM, Haiman CA, Hall JE, Kang JH, Kirpach B, Koenen KC, Kubzansky LD, Lacey, J V., Le Marchand L, Lin X, Lutsey P, Marinac CR, Martinez ME, Milne RL, Murray AM, Nash D, Palmer JR, Patel A V., Pierce E, Robertson MM, Rosenberg L, Sandler DP, Schurman SH, Sewalk K, Sharma S V., Sidey-Gibbons CJ, Slevin L, Smoller JW, Steves CJ, Tiirikainen MI, Weiss ST, Wilkens LR, Zhang F. 2020. Risk of COVID-19 among front-line health-care workers and the general community: a prospective cohort study. Lancet Public Heal 5:e475-e483.

7. Liu Q, Luo D, Haase JE, Guo Q, Wang XQ, Liu S, Xia L, Liu Z, Yang J, Yang BX. 2020. The experiences of health-care providers during the COVID-19 crisis in China: a qualitative study. Lancet Glob Heal 8:e790-e798.

8. Wölfel R, Corman VM, Guggemos W, Seilmaier M, Zange S, Müller MA, Niemeyer D, Jones TC, Vollmar P, Rothe C, Hoelscher M, Bleicker T, Brünink S, Schneider J, Ehmann R, Zwirglmaier K, Drosten C, Wendtner C. 2020. Virological assessment of hospitalized patients with COVID-2019. Nature 581:465-469.

9.

Okba NMA, Müller MA, Li W, Wang C, Geurtsvankessel CH, Corman VM, Lamers MM, Sikkema RS, Bruin E De, Chandler FD, Yazdanpanah Y, Hingrat Q Le, Descamps D, Houhou-Fidouh N, Reusken CBEM, Bosch BJ, Drosten

C, Koopmans MPG, Haagmans BL. 2020. Severe Acute Respiratory Syndrome Coronavirus 2-Specific Antibody Responses in Coronavirus Disease Patients. Emerg Infect Dis 26:1478-1488.

10. Wajnberg A, Amanat F, Firpo A, Altman DR, Bailey MJ, Mansour M, McMahon M, Meade P, Mendu DR, Muellers K, Stadlbauer D, Stone K, Strohmeier S, Simon V, Aberg J, Reich DL, Krammer F, Cordon-Cardo C. 
2020. Robust neutralizing antibodies to SARS-CoV-2 infection persist for months. Science (80- ) 370:eabd7728.

11. Stadlbauer D, Amanat F, Chromikova V, Jiang K, Strohmeier S, Arunkumar GA, Tan J, Bhavsar D, Capuano C, Kirkpatrick E, Meade P, Brito RN, Teo C, McMahon M, Simon V, Krammer F. 2020. SARS-CoV-2 Seroconversion in Humans: A Detailed Protocol for a Serological Assay, Antigen Production, and Test Setup. Curr Protoc Microbiol 57.

12. Anna F, Goyard S, Lalanne AI, Nevo F, Gransagne M, Souque P, Louis D, Gillon V, Turbiez I, Bidard F, Gobillion A, Savignoni A, Guillot $\square$ Delost M, Dejardin F, Dufour E, Petres S, Richard $\square$ Le Goff O, Choucha Z, Helynck O, Janin YL, Escriou N, Charneau P, Perez F, Rose T, Lantz O. 2020. High seroprevalence but short $\square$ lived immune response to SARS $\square$ CoV $\square 2$ infection in Paris. Eur J Immunol https://doi.org/10.1002/eji.202049058.

13. Amanat F, Stadlbauer D, Strohmeier S, Nguyen THO, Chromikova V, McMahon M, Jiang K, Arunkumar GA, Jurczyszak D, Polanco J, Bermudez-Gonzalez M, Kleiner G, Aydillo T, Miorin L, Fierer DS, Lugo LA, Kojic EM, Stoever J, Liu STH, Cunningham-Rundles C, Felgner PL, Moran T, García-Sastre A, Caplivski D, Cheng AC, Kedzierska K, Vapalahti O, Hepojoki JM, Simon V, Krammer F. 2020. A serological assay to detect SARS-CoV-2 seroconversion in humans. Nat Med 26:1033-1036.

14. Figueiredo $\square$ Campos P, Blankenhaus B, Mota C, Gomes A, Serrano M, Ariotti S, Costa C, Nunes $\square$ Cabaço H, Mendes AM, Gaspar P, Pereira $\square$ Santos MC, Rodrigues F, Condeço J, Escoval MA, Santos M, Ramirez M, Melo $\square$ Cristino J, Simas JP, Vasconcelos E, Afonso Â, Veldhoen M. 2020. Seroprevalence of anti $\square \operatorname{SARS} \square \operatorname{CoV} \square 2$ antibodies in COVID $\square 19$ patients and healthy volunteers up to 6 months post disease onset. Eur J Immunol $50: 2025-2040$.

15. Open Data Österreich. 2021. Österreichisches COVID-19 Open Data Informationsportal; https://www.data.gv.at/covid-19/.

16. Harris PA, Taylor R, Minor BL, Elliott V, Fernandez M, O’Neal L, McLeod L, Delacqua G, Delacqua F, Kirby J, Duda SN. 2019. The REDCap consortium: Building an international community of software platform partners. J Biomed Inform. Academic Press Inc.

17. Harris PA, Taylor R, Thielke R, Payne J, Gonzalez N, Conde JG. 2009. Research electronic data capture (REDCap)A metadata-driven methodology and workflow process for providing translational research informatics support. $\mathrm{J}$ Biomed Inform 42:377-381.

18. Yuan M, Wu NC, Zhu X, Lee CCD, So RTY, Lv H, Mok CKP, Wilson IA. 2020. A highly conserved cryptic epitope in the receptor binding domains of SARS-CoV-2 and SARS-CoV. Science (80- ) 368:630-633.

19. Klausberger M, Dürkop M, Haslacher H, Wozniak-Knopp G, Cserjan- M, Perkmann T, Lingg N, Pereira Aguilar P, Laurent E, De J, Hofer M, Holzer B, Stadler M, Manhart G, Vierlinger K, Milchram L, Gludovacz E, Marx N, Köppl C, Tauer C, Beck J, Maresch D, Grünwald-Gruber C, Strobl F, Satzer P, Vavra U, Huber J, Wahrmann M, Eskandary F, Sieghart D, Quehenberger P, Leitner G, Strassl R, Egger AE, Irsara C, Griesmacher A, Hoermann G, Weiss G, Bellmann-Weiler R, Loeffler-Ragg J, Borth N, Strasser R, Jungbauer A, Hahn R, Hartmann B, Binder NB, Striedner G, Mach L, Dieplinger B, Grebien F, Gerner W, Binder CJ, Grabherr R. 2021. A comprehensive antigen 
production and characterization study for easy-to-1 implement, highly specific and quantitative SARS-CoV-2 antibody assays 2 3. medRxiv 2021.01.19.21249921.

20. Korth J, Wilde B, Dolff S, Anastasiou OE, Krawczyk A, Jahn M, Cordes S, Ross B, Esser S, Lindemann M, Kribben A, Dittmer U, Witzke O, Herrmann A. 2020. SARS-CoV-2-specific antibody detection in healthcare workers in Germany with direct contact to COVID-19 patients. J Clin Virol 128.

21. Behrens GMN, Cossmann A, Stankov M V., Witte T, Ernst D, Happle C, Jablonka A. 2020. Perceived versus proven SARS-CoV-2-specific immune responses in health-care professionals. Infection 48:631-634.

22. Fusco FM, Pisaturo M, Iodice V, Bellopede R, Tambaro O, Parrella G, Di Flumeri G, Viglietti R, Pisapia R, Carleo MA, Boccardi M, Atripaldi L, Chignoli B, Maturo N, Rescigno C, Esposito V, Dell'Aversano R, Sangiovanni V, Punzi R. 2020. COVID-19 among healthcare workers in a specialist infectious diseases setting in Naples, Southern Italy: results of a cross-sectional surveillance study. J Hosp Infect 105:596-600.

23. Lahner E, Dilaghi E, Prestigiacomo C, Alessio G, Marcellini L, Simmaco M, Santino I, Orsi GB, Anibaldi P, Marcolongo A, Annibale B, Napoli C. 2020. Prevalence of Sars-Cov-2 infection in health workers (HWs) and diagnostic test performance: the experience of a teaching hospital in central Italy. Int J Environ Res Public Health $17: 1-12$.

24. Plebani M, Padoan A, Fedeli U, Schievano E, Vecchiato E, Lippi G, Lo Cascio G, Porru S, Palù G. 2020. SARSCoV-2 serosurvey in health care workers of the Veneto Region. Clin Chem Lab Med 58.

25. Steensels D, Oris E, Coninx L, Nuyens D, Delforge ML, Vermeersch P, Heylen L. 2020. Hospital-Wide SARSCoV-2 Antibody Screening in 3056 Staff in a Tertiary Center in Belgium. JAMA - J Am Med Assoc. American Medical Association.

26. Trieu M-C, Bansal A, Madsen A, Zhou F, Sævik M, Vahokoski J, Brokstad KA, Krammer F, Tøndel C, Mohn KGI, Blomberg B, Langeland N, Cox RJ. 2020. SARS-CoV-2-specific neutralizing antibody responses in Norwegian healthcare workers after the first wave of COVID-19 pandemic: a prospective cohort study. J Infect Dis https://doi.org/10.1093/infdis/jiaa737.

27. Poulikakos D, Sinha S, Kalra PA. 2020. SARS-CoV-2 antibody screening in healthcare workers in a tertiary centre in North West England. J Clin Virol. Elsevier B.V.

28. Stadlbauer D, Tan J, Jiang K, Hernandez M, Fabre S, Amanat F, Teo C, Asthagiri Arunkumar G, McMahon M, Jhang J, Nowak M, Simon V, Sordillo E, van Bakel H, Krammer F. 2020. Seroconversion of a city: Longitudinal monitoring of SARS-CoV-2 seroprevalence in New York City. medRxiv 2020.06.28.20142190.

29. Venugopal U, Jilani N, Rabah S, Shariff MA, Jawed M, Batres AM, Abubacker M, Menon S, Pillai A, Shabarek N, Kasubhai M, Dimitrov V, Menon V. 2020. SARS-CoV-2 Seroprevalence Among Health Care Workers in a New York City Hospital: A Cross-Sectional Analysis During the COVID-19 Pandemic. Int J Infect Dis 102:63-69.

30. Rashid-Abdi M, Krifors A, Sälléber A, Eriksson J, Månsson E. 2020. Low rate of COVID-19 seroconversion in health-care workers at a Department of Infectious Diseases in Sweden during the later phase of the first wave; a prospective longitudinal seroepidemiological study. Infect Dis (Auckl) 1-7. 
31. Grant J, Wilmore S, McCann N, Donnelly O, Lai R, Kinsella M, Rochford H, Patel T, Kelsey M, Andrews J. 2020. Seroprevalence of SARS-CoV-2 antibodies in healthcare workers at a London NHS Trust. Infect Control Hosp Epidemiol https://doi.org/10.1017/ice.2020.402.

32. Shields A, Faustini S, Perez-Toledo M, Jossi S, Aldera E, Allen J, Al-Taei S, Backhouse C, Bosworth A, Dunbar L, Ebanks D, Emmanuel B, Grey J, Kidd IM, McGinnell G, McLoughlin D, Morley G, O’Neill J, Papakonstantinou D, Pickles O, Poxon C, Richter M, Walker E, Wanigasooriya K, Watanabe Y, Whalley C, Zielinska A, Crispin M, Wraith D, Beggs A, Cunningham A, Drayson M, Richter A. 2020. SARS-CoV-2 seroconversion in health care workers. medRxiv 2020.05.18.20105197.

33. Randolph HE, Barreiro LB. 2020. Herd Immunity: Understanding COVID-19. Immunity 52:737-741.

34. Centers for Disease Control and Prevention. 2021. Coronavirus Disease 2019 (COVID-19); https://www.cdc.gov/coronavirus/2019-nCoV/index.html.

35. Statistik Austria. 2020. $4.7 \%$ of Austrian population had SARS-CoV-2 antibodies at mid/end October; http://www.statistik.at/web_en/press/124960.html.

36. DWH-Technical solutions simulation services. https://www.dwh.at/news/nachtrag-zur-pressekonferenz-vom-19-2$2021 \%$

37. Amanat F, Krammer F. 2020. SARS-CoV-2 Vaccines: Status Report. Immunity. Cell Press.

38. Nilsson AC, Holm DK, Justesen US, Gorm-Jensen T, Andersen NS, Øvrehus A, Johansen IS, Michelsen J, Sprogøe U, Lillevang ST. 2020. Comparison of six commercially available SARS-CoV-2 antibody assays - choice of assay depends on intended use. Int J Infect Dis https://doi.org/10.1016/j.ijid.2020.12.017.

39. Mulligan MJ, Lyke KE, Kitchin N, Absalon J, Gurtman A, Lockhart S, Neuzil K, Raabe V, Bailey R, Swanson KA, Li P, Koury K, Kalina W, Cooper D, Fontes-Garfias C, Shi PY, Türeci Ö, Tompkins KR, Walsh EE, Frenck R, Falsey AR, Dormitzer PR, Gruber WC, Șahin U, Jansen KU. 2020. Phase I/II study of COVID-19 RNA vaccine BNT162b1 in adults. Nature 586:589-593. 


\section{Figures and tables}

\section{Table 1}

\section{Characteristics}

\begin{tabular}{|c|c|}
\hline All participants; \% (n) & $100(395)$ \\
\hline Age; years (min-max) & $42(18-64)$ \\
\hline Female sex; \% (n) & $71(282)$ \\
\hline BMI (min-max) & $25(18-45)$ \\
\hline Overweight or obese, \% (n) & $35(139)$ \\
\hline Current smoking; \% (n) & $18(73)$ \\
\hline Working in COVID-19-hospital; \% (n) & $44(174)$ \\
\hline Children in household; \% (n) & $53(211)$ \\
\hline PCR tested; \% (n) / positive PCR; \%(n) & $63(249) / 13(53)$ \\
\hline
\end{tabular}

Continuous data are given as mean, in the presence of a skewed distribution, mean values are given together with minimum and maximum values (min-max). Dichotomous data are given as proportion. BMI denotes body mass index and PCR polymerase chain reaction. The term children is summarizing all children or adolescents under 25 years. PCR stands for SARS-CoV-2-specific real time reverse transcription PCR. 


\section{Table 2}

\section{Antibody response during study}

\begin{tabular}{|c|c|c|c|c|c|}
\hline & \multicolumn{2}{|c|}{ participants } & RBD & NP & RBD-NP \\
\hline \multirow{3}{*}{$t_{1}$} & all $\mathrm{HCW}$ & $\begin{array}{c}100 \% \\
(n=395)\end{array}$ & $\begin{array}{c}1.66 \\
(0.12-0.89) \mathrm{U} / \mathrm{mL}\end{array}$ & $\begin{array}{c}1.40 \\
(0.15-0.98) \\
U / m L\end{array}$ & $\begin{array}{l}r=0.243 \\
p<0.001\end{array}$ \\
\hline & $\begin{array}{c}\text { seropositive } \\
\text { HCW }\end{array}$ & $\begin{array}{c}6 \% \\
(n=24)\end{array}$ & $\begin{array}{c}18.24 \\
(1.55-10.54) \\
U / m L\end{array}$ & $\begin{array}{c}13.45 \\
(1.94-22.71) \\
U / m L\end{array}$ & $\begin{array}{l}r=0.270 \\
p=0.201\end{array}$ \\
\hline & $\begin{array}{c}\text { seropositive } \\
\text { HCW } \\
\text { with strong } \\
\text { response }\end{array}$ & $\begin{array}{c}3 \% \\
(n=12)\end{array}$ & $\begin{array}{c}32.29 \\
(5.00-35.25) \\
U / m L\end{array}$ & $\begin{array}{c}24.23 \\
(9.35-35.35) \\
U / m L\end{array}$ & $\begin{array}{l}r=-0.028 \\
p=0.931\end{array}$ \\
\hline \multirow{3}{*}{$t_{2}$} & all HCW & $\begin{array}{l}100 \% \\
n=390\end{array}$ & $\begin{array}{c}2.78 \\
(0.04-0.84) \mathrm{U} / \mathrm{mL}\end{array}$ & $\begin{array}{c}1.59 \\
(0.00-0.86) \\
U / m L\end{array}$ & $\begin{array}{l}r=0.305 \\
p<0.001\end{array}$ \\
\hline & $\begin{array}{c}\text { seropositive } \\
\text { HCW }\end{array}$ & $\begin{array}{c}6 \% \\
(n=25)\end{array}$ & $\begin{array}{c}35.55 \\
(4.68-57.16) \\
U / m L\end{array}$ & $\begin{array}{c}17.04 \\
(2.10-25.30) \\
U / m L\end{array}$ & $\begin{array}{l}r=0.338 \\
p=0.098\end{array}$ \\
\hline & $\begin{array}{c}\text { seropositive } \\
\text { HCW } \\
\text { with strong } \\
\text { response }\end{array}$ & $\begin{array}{c}4 \% \\
(n=16)\end{array}$ & $\begin{array}{c}52.38 \\
(7.51-114.10) \\
U / m L\end{array}$ & $\begin{array}{c}24.98 \\
(5.71-39.98) \\
U / m L\end{array}$ & $\begin{array}{l}r=0.206 \\
p=0.444\end{array}$ \\
\hline \multirow{3}{*}{$t_{3}$} & all HCW & $\begin{array}{c}100 \% \\
(n=371)\end{array}$ & $\begin{array}{c}5.17 \\
(0.10-1.09) \mathrm{U} / \mathrm{mL}\end{array}$ & $\begin{array}{c}4.52 \\
(0.22-1.50) \\
U / m L\end{array}$ & $\begin{array}{l}r=0.474 \\
p<0.001\end{array}$ \\
\hline & $\begin{array}{c}\text { seropositive } \\
\text { HCW }\end{array}$ & $\begin{array}{c}17 \% \\
(n=62)\end{array}$ & $\begin{array}{c}28.69 \\
(6.57-33.54) \\
U / m L\end{array}$ & $\begin{array}{c}23.60 \\
(4.93-23.59) \\
U / m L\end{array}$ & $\begin{array}{l}r=0.448 \\
p<0.001\end{array}$ \\
\hline & $\begin{array}{c}\text { seropositive } \\
\text { HCW } \\
\text { with strong } \\
\text { response }\end{array}$ & $\begin{array}{c}14 \% \\
(n=52)\end{array}$ & $\begin{array}{c}33.20 \\
(10.39-45.08) \\
U / m L\end{array}$ & $\begin{array}{c}27.57 \\
(7.71-28.30) \\
U / m L\end{array}$ & $\begin{array}{l}r=0.347 \\
p=0.012\end{array}$ \\
\hline
\end{tabular}

The table summarizes the concentration of SARS-CoV-2 receptor binding domain (RBD) - and nucleocapsid protein (NP) - specific antibody response at the respective time point given as mean (with interquartile range). Correlation $(r)$ is given together with the p-value according to spearman test. Seropositive HCW (comprising a moderate and a strong response) had a concentration of $\geq 5 \mathrm{U} / \mathrm{mL}$ for either RBD or NP-response. Seropositive with a strong response were characterized by a concentration of either $\geq 9 \mathrm{U} / \mathrm{mL}$ for $\mathrm{RBD}$ or $\geq 8 \mathrm{U} / \mathrm{mL}$ for $\mathrm{NP}$. 


\section{Figure Legends}

\section{Figure 1: Study timeline}

The figure presents the 7-day incidence per 100,000 inhabitants in Austria and in the federal state of Vorarlberg between February 2020 and January 2021. The time points of sampling ( $t_{1}, t_{2}$, and $t_{3}$; solid black line) and of harsh lockdown (hatched line) are marked.

\section{Figure 2: Concentration and spread of RBD- and NP-specific IgG response}

SARS-CoV-2-specific anti-RBD and anti-NP-specific IgG response of study participants is depicted at study time point $t_{1}(A), t_{2}(B)$, and $t_{3}(C)$. A reference range of $0-5 \mathrm{U} / \mathrm{mL}$ representing no response is separated from a moderate positive response ( $\geq 5$ and $<9 \mathrm{U} / \mathrm{mL}$ for anti-RBD $\lg G$ and $\geq 5$ and $<8 \mathrm{U} / \mathrm{mL}$ for anti-NP $\lg G$ ) by a dashed green line and from a strong positive response ( $\geq 9 \mathrm{U} / \mathrm{mL}$ for anti-RBD and $\geq 8 \mathrm{U} / \mathrm{mL}$ for anti-NP) by a solid green line. The solid grey line represents a linear regression line $\left(R^{2}\right)$.

\section{Figure 3: Shift of RBD- and NP-specific IgG response during study}

SARS-CoV-2-specific IgG responses of study participants at time point $\mathrm{t}_{1}$ (black rhombs), are depicted ordered from high to low/background. The reference range $(<5 \mathrm{U} / \mathrm{mL})$ representing no response is separated from a moderate positive response ( $\geq 5$ and $<9$ for anti-RBD and $\geq 5$ and $<8$ for anti-NP) by a dashed green line and from a strong positive response ( $\geq 9 \mathrm{U} / \mathrm{mL}$ for anti-RBD and $\geq 8 \mathrm{U} / \mathrm{mL}$ for anti-NP) by a solid green line. The matching responses at $t_{2}$ (circles), and $t_{3}$, (triangles) are connected by a vertical line. RBD-specific responses are represented by orange (for $t_{2}$ ) and red (for $t_{3}$ ) symbols, NP-specific responses by turquois (for $t_{2}$ ) and purple (for $t_{3}$ ) symbols. 


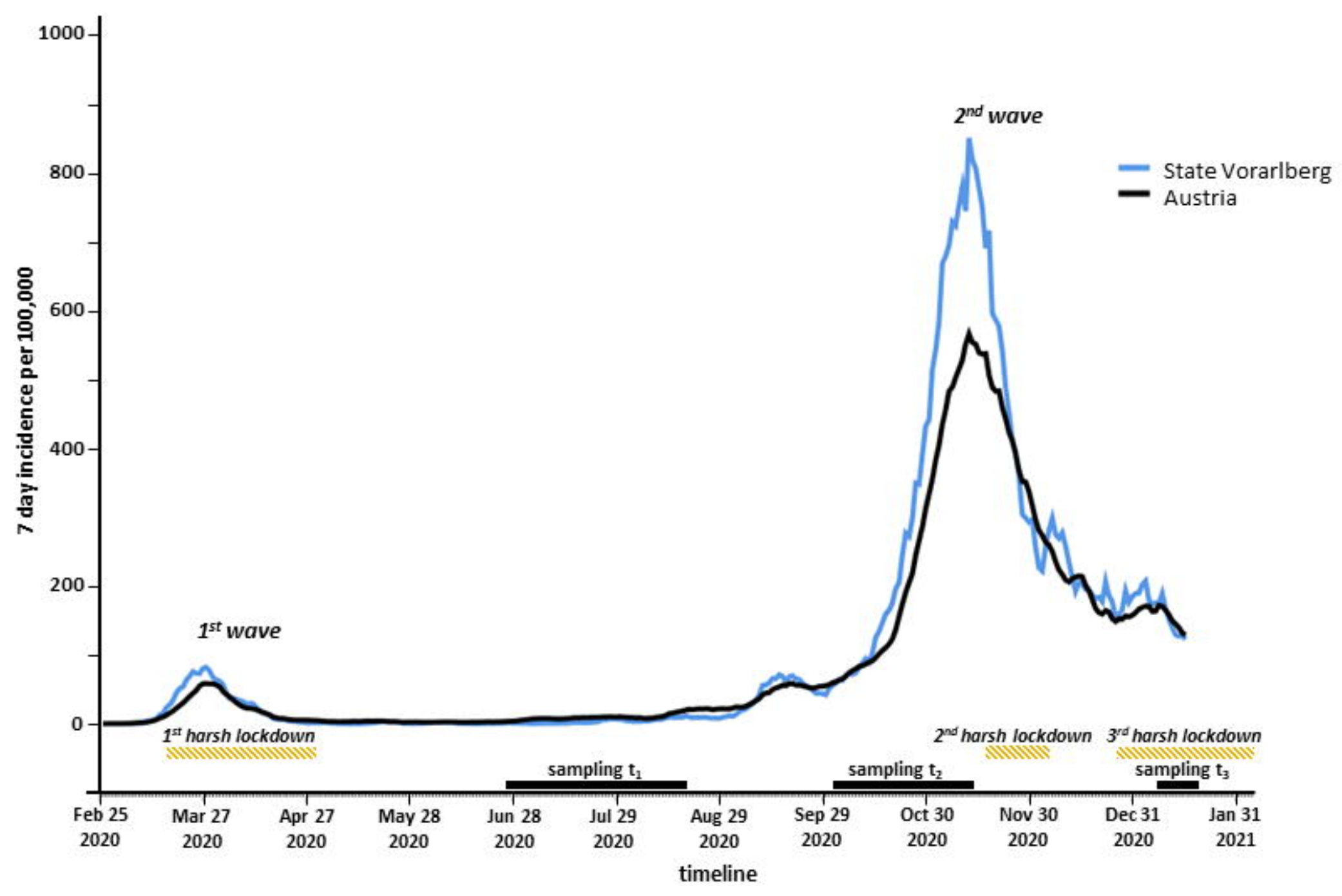


A

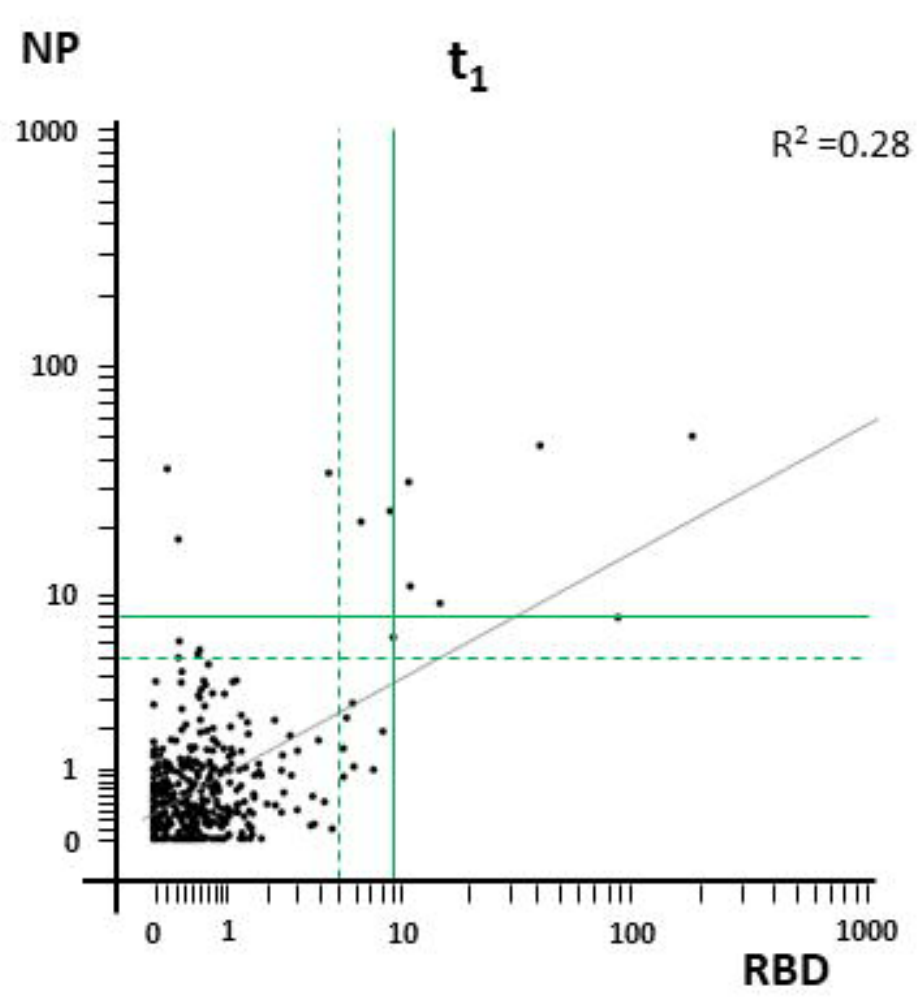

B

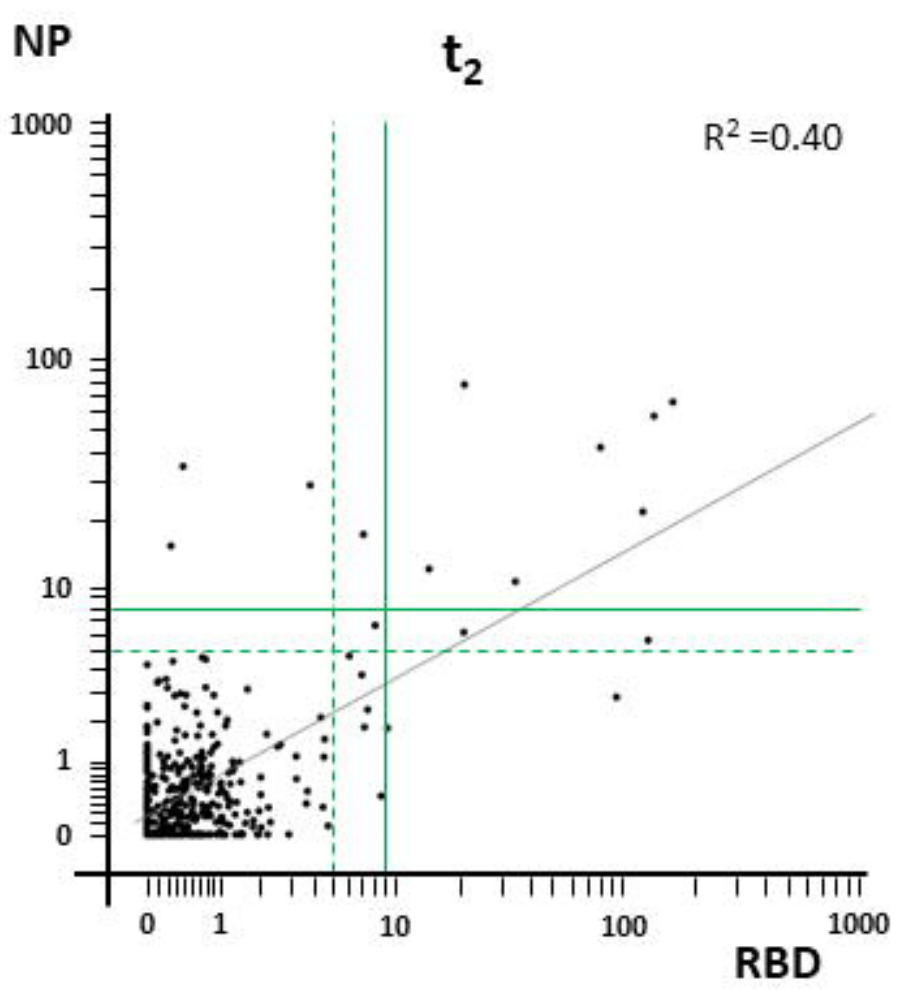

C

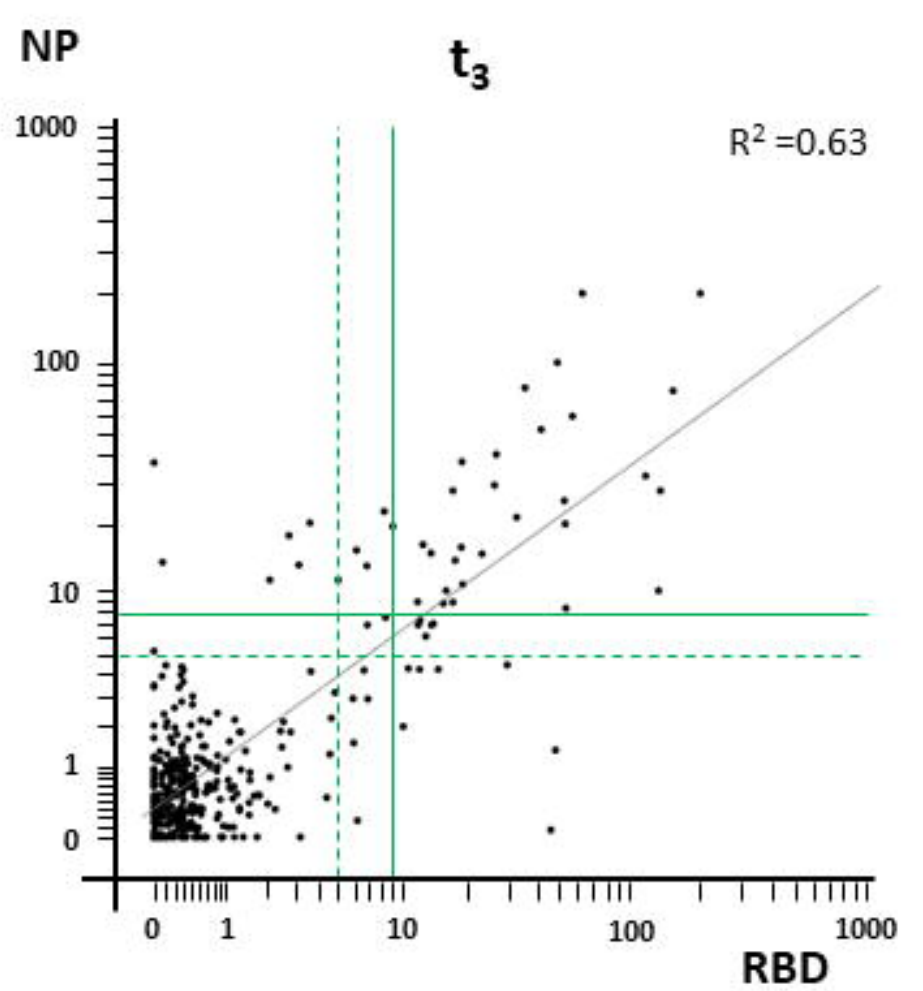


RBD

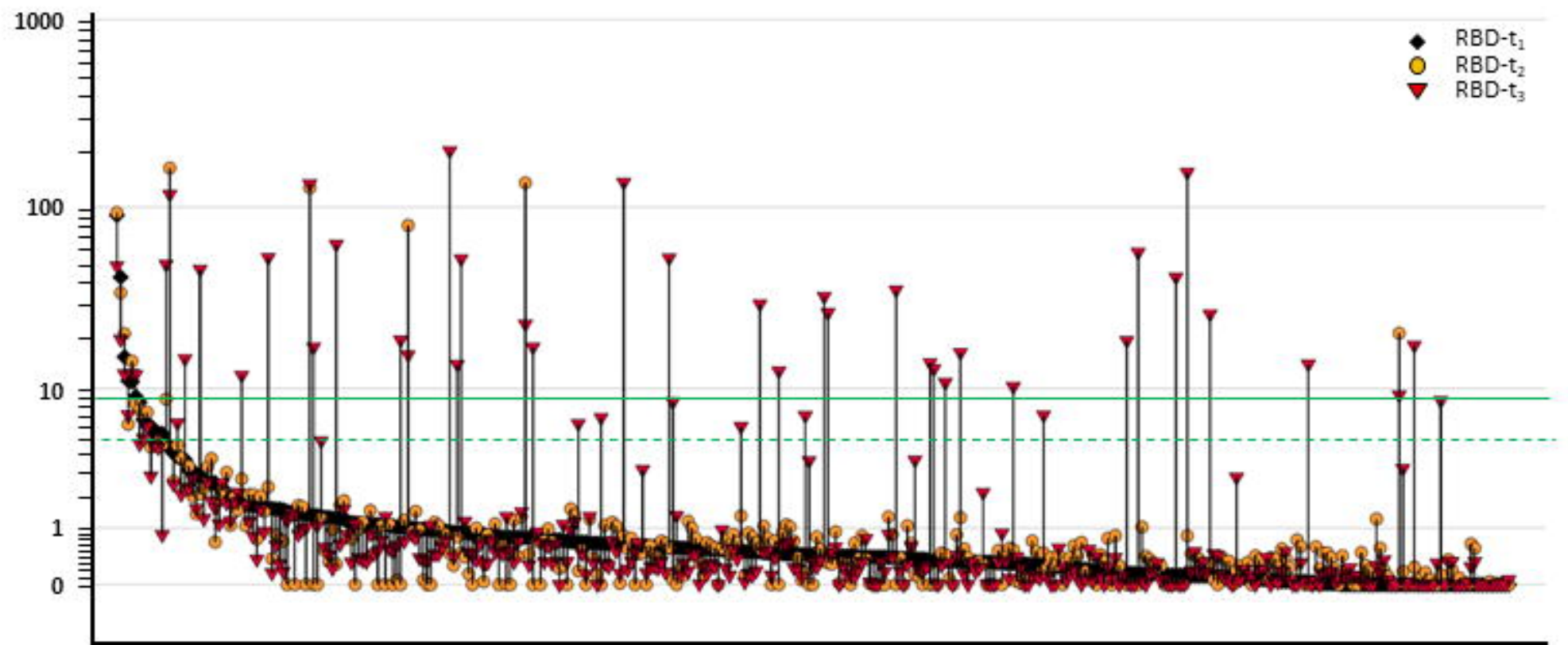

NP

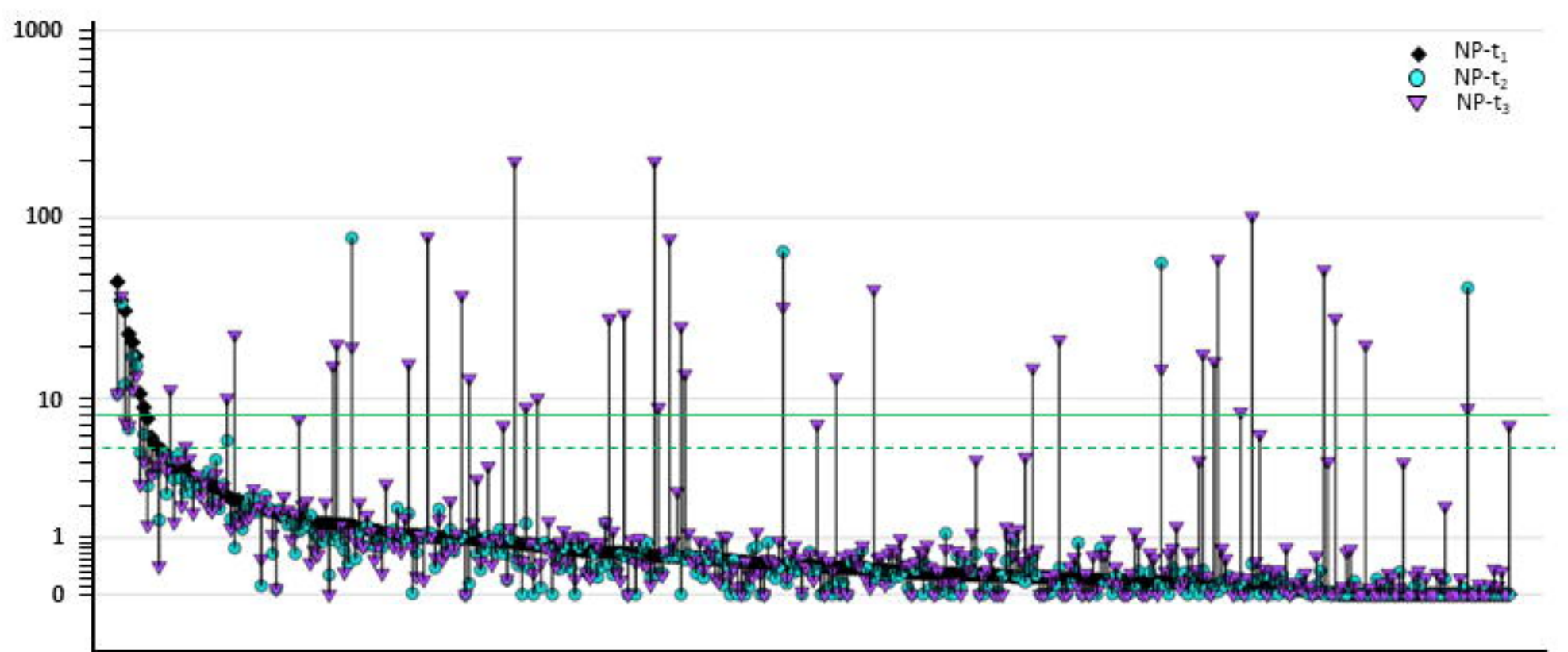

